\title{
Opinions of Investors on Nepal Stock Exchange Limited (NEPSE) Online Trading System
}

\author{
Rashesh Vaidya \\ Faculty of Management, Siddharth Vanasthali College of Management \\ Kathmandu, Nepal
}

Article History: Submitted 12 February 2021; Reviewed 18 April 2021; Accepted 20 April 2021 Corresponding Author: Rashesh Vaidya, Email: rashesh_vaidya@hotmail.com DOI: https://doi.org/10.3126/paj.v4i0.37015

Copyright 2021 (c) Author/s and Centre for Research and Innovation. This work is licensed under a Creative Commons Attribution 4.0 International (CC BY 4.0) License.
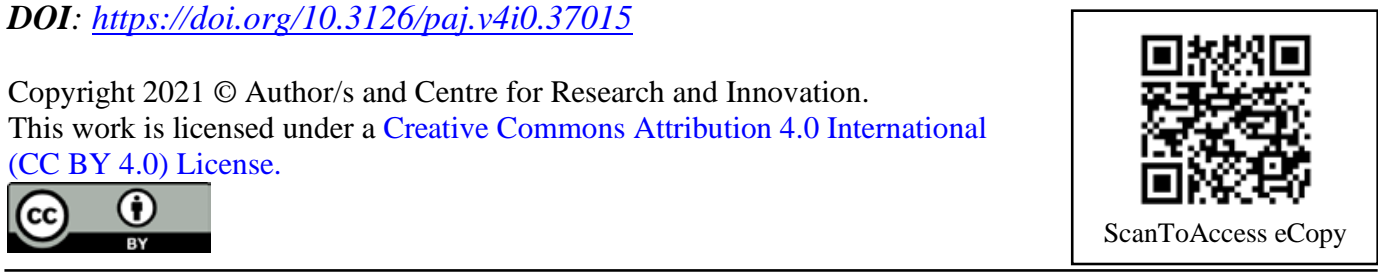

\begin{abstract}
Nepal Stock Exchange Limited (NEPSE) is only a secondary market in Nepal. After almost three decades of its establishment, the NEPSE trading system turned fully automated on January 17, 2021. The new system is named NEPSE Online Trading System (NOTS), which was launched on November 6, 2018. After the breakout of the COVID-19, the NOTS users using NEPSE online Trade Management System (TMS) and Uniform Resource Locator (URL) increased due to the nation-wide lockdown as well as the compulsion from the governing body. Hence, the paper attempts to get opinions from the NOTS users about its features and performance. The paper has taken 300 NOTS users as samples for the survey purpose. The online survey was conducted for the study. A 5-points Likert scale-based questionnaire was forwarded to the potential online traders (investors) through an online platform such as messenger and email. The study has followed descriptive statistics and a one-sample t-test to interpret the collected data from the NOTS users. The study found that there is an issue of the market data display in the NOTS platform, which needs to be addressed as soon as possible. At the same time, the respondents stated that the best parts of NOTS were that it has helped them to specify and customize the securities, price, and volume that one would like to trade on a realtime basis.
\end{abstract}

KEYWORDS: Trading system, NEPSE, NOTS, online trading, investors

\section{INTRODUCTION}

Nepal Stock Exchange Limited (NEPSE) is the only secondary market of Nepal that opened its trading floor on February 19, 1994. Earlier, a Securities Exchange Center Limited was in operation since 1976. With an initiation to reform the capital market of Nepal, the existing Securities Exchange was converted into NEPSE (www.nepalstock.com.np). 
The trading system at NEPSE was based on Open-out-Cry till 2007. On August 24, 2007, NEPSE adopted a semi-automated screen-based trading system by setting up a Wide Area Network (WAN). With the establishment of CDS \& Clearing Limited on March 31, 2011, a new era of the stock market started in Nepal. The dematerialization of the securities started in Nepal (www.nrb.org.np).

NEPSE conducted electronic trading of securities on April 15, 2014 for the first time, following the phase-wise implementation of online trading at NEPSE. On October 8, 2014, NEPSE started the first phase of trading dematerialized shares of the banking sector. The settlement of traded shares was done online for the first time at NEPSE through CDS \& Clearing Limited (Nepal Stock Exchange Limited, 2020).

Securities Board of Nepal (SEBON) and CDS \& Clearing Limited declared to carry out the securities transaction only for dematerialized securities from January 15, 2016. The electronic settlement of the dematerialized securities was started on October 7, 2018, by the implementation of the Electronic Delivery Instruction Slip (EDIS). NEPSE started an internet-based fully automated online trading system on November 6, 2018. It is termed as NEPSE Online Trading System (NOTS). The implementation of NOTS has been a milestone in the history of NEPSE. NEPSE completely stopped the physical trading of securities from January 17, 2021 (CDS \& Clearing Ltd., 2021).

NOTS features twenty modules related to the internal control system. They are namely, organization and users management, responsibility and authority management, listings management, index management, matching engine, brokers management, collateral management, the price related real-time information flow, risk management system, supervision system, brokers back-office management, order route management, market makers, members portal, member admin terminal, traders work-stations-Investor, traders work-stations-broker, controlling work-station exchange massaging system, and management information system and reporting (Nayak, 2018).

Kadariya et al. (2012) pointed out in their paper that due to the lack of an online trading system in NEPSE, investors were not able to get the information on a real-time basis. In addition to the implementation and rise in the NOTS users, the representative of the Investors Association of Nepal pointed out that NOTS upset the investors and was not as per the expectation of investors. As the NOTS was expected to complete a transaction within 50 microseconds as stated by NEPSE, but after the full automation of the NOTS, the settlement time per transaction was more than three minutes (www.thehimalyantimes.com). The study will help to disclose, how the launch of the online trading system at the NEPSE has value-added in the trading mechanism of NEPSE from the viewpoint of the NOTS users (investors).

In this historical backdrop, with a short duration of just about two years of implementation of NOTS and the rise of the NEPSE Trade Management System (TMS) Uniform Resource Locator (URL) gateway after the break-out of the COVID-19 pandemic, the paper tries to find out the opinion on the online trading system of NEPSE among the NOTS users.

\section{REVIEW OF LITERATURE}

Majer (1997) examined among the 42 Canadian stock market investors on issues ranging from internet securities to their willingness to adopt online-based stock trading in Canada. He concluded that the trend would catch a valuable niche market in electronic commerce.

Loh and Ong (1998) examined the opinion on online stock trading among the investors of Singapore. They revealed that the expectation and concern of investors, belief, and attitude towards going online trading, perceived ease of use and real value- 
added in the system as well as trading behavior determined an adaptation of online stock trading.

Lau et al. (2001) found that perceived usefulness, perceived ease of use, and the compatibility significantly influence attitude towards online stock trading. They also found that after the implementation of an online trading system, improvements in the placement of orders were visible in the market.

Lee-Partridge and Ho (2003) studied the factors that influenced in the growth of online stock trading in Singapore. The study revealed that attitude and social factors significantly influence investors' intention towards adopting internet stock trading.

Singh et al. (2010) compared opinions on online stock trading between adopters and non-adopters of online stock trading. They found that attitude and demographic dimensions significantly contribute to adopting online stock trading. They also found that as per attitude the variety of financial product and safety concerns followed by convenience and transparency determined in being adopter or non-adopter. At the same time, as per demographic perspective, mature, experienced, and businessmen investors were not interested in online stock trading.

Srivastava (2011) found that paperless trading of stock had reduced the risk of manipulations but at the same time she found concern about the securities regarding the transaction in the growing digital regime.

Amsaveni and Gomathi (2012) revealed that stock traders were satisfied with the communication, responsiveness, facilities, and services provided by the online share trading platform providers. They also found that mental pressure, connectivity problems, and lack of confidentiality of personal information were seen as issues in the online trading platform.

Tai and $\mathrm{Ku}$ (2013) found that the Taiwanese stock investors were positive towards the performance expectancy, effort expectancy, and social influence and negative towards the security risk, economic risk, and financial risk while going for the online stock trading.

Hou (2015) investigated how demographic factors and the use of the internet influence online stock trading among American and Chinese stock market traders. He found that mainly the male traders with easy access to the internet preferred to go for online trading. He also found that the American online traders were less concerned with the security in online stock trading than the Chinese online traders.

Bhuvanam and Mohan (2015) studied the investors' behavioral intentions towards the online trading system at the stock exchange of Tiruchirappalli City. He found that the online trading system had made transactions easier, quicker, and trustworthy. He also found that the investors were sure of the misuse or unauthorized dealing from the system without proper authorization of the personal users.

Kranthi (2016) found that most online stock traders prefer online payment for transactions. He also found that after the operation of online stock trading, the depository systems had also reduced the lag in delivery and settlement of securities which ultimately benefited in improving market liquidity.

Singh and Malhotra (2016) found that among the demographic factors like homeownership, income, trading experience and occupation did not affect the adoption of online trading but marital status, age, gender, education, type of trade and trading frequency affected the adoption of online trading. Similarly, perceived benefit and perceived risk have no direct impact on the adoption of online trading.

Renuka (2017) found that online stock trading was preferred more than offline trading as it was more investor (user) friendly and convenient to use. 
Sakthivel and Saravanakumar (2018) investigated Coimbatore district investors' satisfaction with online share trading and the technical problem faced by them while trading at BSE and NSE. They found that most of the online users were satisfied, though expected for better services. They found operational difficulties, email association, and lack of analytical skills as major technical issues overcome by users.

Rawal and Chowdhury (2018) studied the perception of investors from Faridabad on the online trading system of the Indian stock market. They studied the relationship between the demographic factors and opinions on online trading facilities at major Indian stock markets. They found that there was a positive relationship between the facilities provided by stock brokerage houses and the income level and gender of the online traders.

Bansal et al. (2018) elaborated on the problems and prospects of online stock trading in Solon Town of Himachal Pradesh. They found eagerness among the investors in trading online to get at least the amount initially invested. The study found the investors were satisfied with the choice available in the trading platform. They also found that the problem of hacking the security system was quite common and need to be reviewed timely.

Navya and Veeraiah (2019) found that social interaction among the investors and the positive news from the media regarding online stock trading was highly influenced by the online stock trading. They also found that the trading frequency through online platforms was also highly influenced by social interaction and media news.

Biradar (2019) concluded that the less time-consuming and the less transaction cost were the main two reasons that an investor preferred to go for online stock trading.

Dhakshana et al. (2020) examined the trader's perception difference between a traditional trading system and an online trading system among investors of the Thanjavur district. They found that the quick information update under the online trading system has attracted the traders in place of the traditional trading system.

\section{METHODOLOGY}

The paper has followed a descriptive research design. The paper has tried for fact-finding regarding the opinion on the NEPSE Online Trading System (NOTS) using NEPSE Trade Management System (TMS) Uniform Resource Locator (URL) gateway, among the online traders.

The paper has considered only online traders or NEPSE Online Trading System (NOTS) users at the beginning of the year 2021 as a population. At the beginning of the year 2021, a total of about 200,000 NOTS users were recorded, as per NEPSE data. A total of 300 NOTS users (considering a 90 percent confidence level with a five percent margin of error) have been taken as a sample for the paper from the total NOTS users. Hence, the paper has followed the purposive sampling technique.

The paper has adopted a 5-point Likert scale to get opinions on the NOTS with a score of ' 1 ' for 'Least agreed' and a score of ' 5 ' for 'Most agreed'. The paper has adopted the questionnaire items of Singh, Sandhu and Kandu (2010) that are relevant to the Nepali context, and further items were developed as per the features of the existing NOTS trading platform. Mainly, the convenience and transparency dimension, sitecustomization, and awareness with variety and safety dimensions of the online stock trading platform have been accompanied in the paper.

The primary data was collected through an online survey. A questionnaire was developed in Google Form. The targeted sample investors were verified as potential TMS users through the short communication on Messenger. Then, the link of the online 
questionnaire was sent to the TMS users through Messenger and email. The response rate of the questionnaire was more than 90 percent.

After taking responses from the 50 NOTS users, Cronbach's Alpha was calculated for the validity of the questionnaire. Initially, 11 (eleven) items were included in a questionnaire that was relevant regarding the NOTS. After a pilot study among 50 NOTS users, the Likert items, 'NOTS leads to excessive delay in order execution and confirmation,' 'NOTS needs to be improved,' 'Navigation of NEPSE Trade Management System (TMS) is an investor friendly' and 'NOTS have reduced the settlement time' were dropped from the questionnaire. Then, the remaining seven itemsbased questionnaires [Cronbach's Alpha $(\alpha)=0.742$ ] were messaged or emailed to the remaining 250 respondents.

The paper has calculated the descriptive statistics and one-sample t-test (parametric test) to analyze and interpret the opinions forwarded by the respondents.

\section{RESULTS AND DISCUSSION}

\section{Description of the Online Traders}

The table below illustrates the gender and the age group of the online traders (respondents):

\section{Table 1}

Gender and Age Group of the Online Traders

\begin{tabular}{llllll}
\hline Gender & Frequency & Percent & Age Group & Frequency & Percent \\
\hline Female & 24 & 8.0 & $16-30$ & 142 & 47.3 \\
Male & 276 & 92.0 & $30-40$ & 96 & 32.0 \\
& & & $40-50$ & 42 & 14.0 \\
& & 50 and above & 20 & 6.7 \\
\hline Total & $\mathbf{3 0 0}$ & $\mathbf{1 0 0 . 0}$ & Total & $\mathbf{3 0 0}$ & $\mathbf{1 0 0 . 0}$ \\
\hline
\end{tabular}

Source: Online Survey, 2021

Table 1 shows the composition of the gender and age group of the respondents. Of the total respondents, a majority (92 percent) were male online traders. As per the age group, a majority (47.3 percent) of the traders were from the age group of 16-30 years. Only 6.7 percent of the online traders were seen from the age group of 50 years and above.

\section{Trading Experience of the Online Traders} respondents:

The table below illustrates the online trading experience at NEPSE of the

\section{Table 2}

Trading Experience of the Online Traders

\begin{tabular}{lll}
\hline Trading Experience & Frequency & Percent \\
\hline Less than 6 months & 120 & 40.0 \\
Less than a year & 38 & 12.7 \\
1-2 years & 68 & 22.7 \\
More than 2 years & 74 & 24.7 \\
\hline Total & $\mathbf{3 0 0}$ & $\mathbf{1 0 0 . 0}$ \\
\hline
\end{tabular}

Source: Online Survey, 2021

Table 2 shows the trading experience of the respondents. The NEPSE online trading started only on November 6, 2018. It has been only about two years that NEPSE 
adopted NOTS. Hence, the large number of investors, i.e., 40 percent of the total respondents are seen having a trading experience of fewer than six months.

Similarly, other online traders who have experience of online trading of a year or more stated that they took the service of NOTS due to the rise in cases from the COVID19 pandemic. Similarly, 24.7 percent of the respondents stated that they have been using the NOTS from the early days of starting of NOTS service by NEPSE.

\section{Descriptive Statistics and Parametric Test (One Sample T-Test) for the Likert Items}

Table 3 elaborates the descriptive statistics for the responses made for Likert items related to the opinion on online trading system of NEPSE and one sample t-test result for respective items:

Table 3

Descriptive Statistics and Parametric Test (One Sample T-Test) for Likert Items

\begin{tabular}{|c|c|c|c|c|c|c|c|}
\hline Items & Mean* & $\begin{array}{l}\text { Std. } \\
\text { Deviation }\end{array}$ & Skewness & S.E. & Kurtosis & S.E. & $\begin{array}{l}\text { One } \\
\text { Sample } \\
\text { T-Test }^{\dagger}\end{array}$ \\
\hline $\begin{array}{l}\text { NEPSE Online Trading } \\
\text { System (NOTS) data } \\
\text { display is effective. }\end{array}$ & 3.08 & 1.14 & +0.06 & 0.14 & -0.75 & 0.28 & $\begin{array}{l}8.80 \\
(0.000)\end{array}$ \\
\hline NOTS reduced & 3.35 & 1.22 & -0.33 & 0.14 & -0.74 & 0.28 & $\begin{array}{l}12.09 \\
(0.000)\end{array}$ \\
\hline $\begin{array}{l}\text { NOTS have reduced } \\
\text { transaction time to } \\
\text { almost nil due to push } \\
\text { the order directly to the } \\
\text { web server. }\end{array}$ & 3.49 & 1.22 & -0.44 & 0.14 & -0.55 & 0.28 & $\begin{array}{l}14.04 \\
(0.000)\end{array}$ \\
\hline $\begin{array}{l}\text { NOTS helped in better } \\
\text { risk management like } \\
\text { limit of the total } \\
\text { transaction, limit on } \\
\text { total securities traded } \\
\text { and limit on total capital } \\
\text { traded. }\end{array}$ & 3.56 & 1.13 & -0.38 & 0.14 & -0.69 & 0.28 & $\begin{array}{l}16.33 \\
(0.000)\end{array}$ \\
\hline $\begin{array}{l}\text { Transaction is more } \\
\text { transparent. }\end{array}$ & 3.75 & 1.05 & -0.51 & 0.14 & -0.36 & 0.28 & $\begin{array}{l}20.74 \\
(0.000)\end{array}$ \\
\hline $\begin{array}{l}\text { NOTS has enhanced } \\
\text { market quality through } \\
\text { improved liquidity, by } \\
\text { increasing quote } \\
\text { continuity and market } \\
\text { depth facility. }\end{array}$ & 3.83 & 1.05 & -0.64 & 0.14 & -0.34 & 0.28 & $\begin{array}{l}21.97 \\
(0.000)\end{array}$ \\
\hline $\begin{array}{l}\text { Allow to specify and } \\
\text { customize the securities, } \\
\text { price, and volume one } \\
\text { would like to trade on a } \\
\text { real-time basis. }\end{array}$ & 3.88 & 1.10 & -0.69 & 0.14 & -0.29 & 0.28 & $\begin{array}{l}21.67 \\
(0.000)\end{array}$ \\
\hline
\end{tabular}

*Value of the mean is in ascending order.

tSig. two-tailed at $5 \%$ and value at parenthesis is p-value.

Source: Online Survey, 2021

The respondents were not seen satisfied with the display of data at the platform of NEPSE TMS. The average score for the statement, 'NOTS data display is effective.' was towards least agreed (3.08 points). After the effectiveness of the NOT data display, the NEPSE TMS users pointed out the settlement issue. The average score for the statement, 'NOTS reduced settlement risk.' was 3.35 points. 
Similarly, after a full-fledged implementation of NEPSE TMS, the investors expected a heavy decline in the transaction period, but they did not get as expected. The average score for the statement, 'NOTS have reduced transaction time to almost nil due to pushing the order directly to the webserver.' was seen at 3.49 , which is also seen closer to least agreed.

The item, 'NOTS helped in better risk management like a limit of the total transaction, the limit on total securities traded and limit on total capital traded' has got an average score of 3.75 points which shows NOTS users argued that these facilities are in control of brokers and not in the TMS users' hand. Nevertheless, the TMS users agreed that they are getting benefits from limited facilities.

The online traders agreed that the transaction from NOTS is more transparent. The average score for the item, 'Transaction is more transparent' was at 3.75 points, which is closer towards agreed. The paperless, as well as cashless transaction through NOTS, has been more transparent than the earlier trading platform of NEPSE.

The facility of getting to the market depth in a NOTS is a preferred side of the NEPSE TMS users. Similarly, the facilities to get information about scrips trade through 'Order Management' and the detailed information regarding the specific listed companies through 'Market Depth' scored an average of 3.83 points.

The most agreed side of the NOTS by online traders was, it 'allows to specify and customize the securities, price, and volume one would like to trade on a real-time basis' with an average score of 3.88 points.

The skewness for 'NEPSE Online Trading System (NOTS) data display is effective' is only seen positive. The skewness for the remaining items is seen as negative. Similarly, the value of kurtosis is seen as negative which shows the distribution of data is platykurtic. The results from a measure of dispersion show that there is an issue with the effectiveness of data display at NEPSE TMS from the perspective of the NOTS users. Similarly, the distribution results reflect that the NOTS users have not been at a point to give an extreme opinion towards the NOTS implemented by NEPSE. At the same time, the results of the one-sample t-test for all the Likert items were seen as significant.

\section{CONCLUSION AND RECOMMENDATION}

The implementation of a full-fledged NEPSE online trading system (NOTS) has brought both challenges and opportunities to the investors at NEPSE, as well as, to the governing bodies. An investor goes for online trading taking a NOTS service with high expectation, for instance, to get market information on a real-time basis. But the NOTS users stated that they found a technical glitch in the display of data at NOTS.

The governing body Securities Board of Nepal (SEBON) has directed CDS \& Clearing Ltd. to implement T+2 (settlement within 2 days) on January 8,2021. Despite the changed provision, investors are facing a settlement risk. The NOTS users are also facing problems in the smooth operation of NOTS. They found some delay in order executions and settlements. And the consequences of facing the provision of a close-out penalty of 20 percent of the sales amount due to a technical glitch in the server of NOTS by an investor have been a major concern in the due process of $\mathrm{T}+2$ settlement.

The NOTS users were seen satisfied with getting better market depth and freedom to specify the scrips, volume, and price for trading on a real-time basis after NEPSE adopted a fully automated trading system through NOTS. Nevertheless, NEPSE needs to use mass media to educate and familiarize the features and usage procedures of NOTS. It seems that the 'User's Manual for Investors' has not been sufficient to make NOTS friendly among the Nepali investors. 
One of the main issues that need to be addressed is the integration of the NOTS user account with the investor's bank account. This might further reduce the settlement time and address the issue of the settlement risk. The governing bodies and NEPSE should also be alert on the mismatch of transaction records at the NOTS platform, as well as issues of 'Trading Bots' penetrating NOTS. Hence, a strong Firewall should be developed to maintain the secrecy of transactions through NOTS or, even a crash of the NOTS.

\section{REFERENCES}

Amsaveni, R., \& Gomathi, S. (2012). A study on satisfaction of online share traders with special reference to Coimbatore District of Tamil Nadu in India. Asia-Pacific Journal of Management Research and Innovation, 8(2), 145-153. https://doi.org/10.1177/ 2319510X1200800207

Bansal, A., Kashyap, N., Mehta, P., \& Raina, K.K. (2018). A study on problems and prospects of online stock trading in Solan Town of Himachal Pradesh. International Journal of Economic Plants, 5(4), 184-191. https://doi.org/ 10.23910/IJEP/2018.5.4.0273

Barber, B.M., \& Odean, T. (2002). Online investors: Do the slow dies first? The Review of Financial Studies, 15(2), 455-487. https://doi.org/10.1093/rfs/15.2.455

Bhuvanam, S., \& Mohan, R.S. (2015). A study on customers' behavioral intentions towards online trading system in Tiruchirappalli city. International Journal of Management, 6(4), 19-34. http://www.iaeme.com/MasterAdmin/ Journal_ uploads/IJM/VOLUME_6_ISSUE_4 /10120150604003.pdf

Biradar, J. (2019). Investors perception towards online trading with reference to Karvy Stock Broking Company Ltd. at Raichur. International Journal of Business and Management Invention, 8(04), 01-07. http://www.ijbmi.org/papers/Vol(8)4/ Series-5/A0804050107.pdf

CDS \& Clearing Ltd. (2021, January 18). Notice regarding Clearing and Settlement Cycle on T+2. https://cdsc.com.np/Home/news/2021_01_18_12_58_18_ Notice\%20regarding\%20

Clearing\%20and\%20Settlement\%20Cycle\%20on\%20T+2\%20.pdf

Dhakshana, J.D.A., Krishnapriya, V., \& Rajandran, V.R. (2020). The game changer: Perception of traders towards online trading and traditional trading. International Journal of Disaster Recovery and Business Continuity, 11(1), 896-901. http://sersc.org/journals/index.php/ IJDRBC/article/view/8690

Hou, J. (2015). Online stock trading: Do demographics, internet usage, and attitudes matter? International Journal of Business and Social Science, 6(2), 8-15. https://ijbssnet.com/journals/Vol_6_No_2_February_2015/2.pdf

Kadariya, S., Subedi, P.P., Joshi, B., \& Nyaupane, R.P. (2012). Investor Awareness and Investment on Equity in Nepalese Capital Market. Banking Journal, 2(1), 1-15. https://doi.org/ 10.3126/bj.v2i1.5702

Kranthi, E.C. (2016). A study on online trading at Karvy Stock Broking Limited. International Journal of Research in Applied Management, Science \& Technology, 1(2), 1-9. http://zenonpub.com/images/pdf-files/Vol1-Issue2/ 7.Kranthi.pdf

Lau, A., Yen, J., \& Chau, P.Y.K. (2001). Adoption of on-line trading in the Hong Kong financial market. Journal of Electronic Commerce Research, 2(2), 58-65. http://www.jecr.org/ sites/default/files/02_2_p02.pdf

Lee-Partridge, J.E., \& Ho, P.S. (2003). A retail investor's perspective on the acceptance of internet stock trading. Proceedings of the 36th Annual Hawaii International 
Conference on System Sciences, Big Island, Hawaii, USA., 191-192. https://doi.org/10.1109/ HICSS.2003.1174437

Loh, L., \& Ong, Y-S. (1998). The adoption of internet-based stock trading: A conceptual framework and empirical results. Journal of Information Technology, 13(2), 8194. https://doi.org/10.1177/026839629801300202

Majer, A. (1997). Internet stock exchange survey. The Journal of Internet Business. 2(1), 1-3. https://www.icommercecentral.com/open-access/internet-stock-exchangesurvey-2-1.pdf

Navya, V., \& Veeraiah, K. (2019). Investor attitude towards online trading and offline trading. International Journal of Research, 6(10), 1156-1175. https://journals.pen2print.org/ index.php/ijr/article/view/19463/19107

Nayak, N.S. (2018). What's in a package? An overview of NOTS. Nepal Stock Exchange Limited 25th Anniversary Souvenir, pp. 151-155. http://nepalstock.com/ uploads/files/news/ 4f5cb581313edce81dbbc0b4a6c24cbf.pdf

Nepal Rastra Bank (2017, April 27). NRB Samachar 62 ${ }^{\text {nd }}$ Anniversary Publication. https://www.nrb.org.np/ofg/anniversary_publications/NRB_Samachaar_62nd_an niversary_publication_2074_Baishak.pdf

Nepal Stock Exchange Limited (2020, September 24). Trade Management System User Manual: Internet based Fully Automated Online Trading System. YCO Private Limited. http://www.nepalstock.com/news/detailspopup/tms-user-manual-forclients-updated

Nepal Stock Exchange Limited (2021, April 18). About Us. http://www.nepalstock.com/ about-us/introduction

Rawal, P., \& Chowdhury, J.K. (2018). Online trading system in Indian stock market: An empirical study. ZENITH International Journal of Business Economics \& Management Research, 8(2), 227-235. https://www.indianjournals.com/ ijor.aspx?target=ijor:zijbemr \& volume $=8 \&$ issue $=2 \&$ article $=019$

Renuka, N. (2017). A study on customer awareness towards online trading. Anveshana's International Journal of Research in Regional Studies, Law, Social Sciences, Journalism and Management Practices, 2(3), 52-59. http://publications. anveshanaindia.com/wp-content/uploads/2018/06/A-STUDY-ON-CUSTOMERAWARENESS-TOWARDS-ONLINE-TRADING.pdf

Sakthivel, N., \& Saravanakumar, A. (2018). Investors' satisfaction on online share trading and technical problems faced by the investors: A study in Coimbatore District of Tamilnadu. International Journal of Management Studies, 5(3(9)), 71-76. https://doi.org/10.18843/ IJMS/V5I3(9)/10

Securities Board of Nepal (2021, March 23). Securities Transaction Clearing and Settlement Byelaws (Fifth Amendment). http://sebon.gov.np/uploads/uploads/ JPjW97slsopUEGvKH Jb30AEvt6VosNHVWh21p60u.pdf

Singh, A., \& Malhotra, M. (2016). Factors influencing the adoption of online trading: A study of individual investors. IOSR Journal of Business and Management, 18(10), 21-26. https://doi.org/10.9790/487X-1810022126

Singh, A., Sandhu, H.S., \& Kundu, S.C. (2010). Investors' adoption of internet stock trading: A study. Journal of Internet Banking and Commerce, 15(1), 1-21. https://www.icommercecentral.com/open-access/investors-adoption-of-internetstock-trading-a-study.php?aid=38284

Srivastava, S. (2011). Impact of internet growth on the online stock trading in India. Journal of Internet Banking and Commerce, 16(3), 1-10. https://www.icommercecentral.com/open-access/impact-of-internet-growth-onthe-online-stock-trading-in-india.php?aid=38288 
Tai, Y-M., \& Ku, Y-C. (2013). Will stock investors use mobile stock trading? A benefitrisk assessment based on a modified UTAUT model. Journal of Electronic Commerce Research, 14(1), 67-84. http://www.jecr.org/sites/default/files/14_ 01_p5.pdf

The Himalayan News Service. (2018, November 15). Problems in NEPSE's online system upset traders. https://thehimalayantimes.com/business/problems-innepses-online-system-upset -traders 